\title{
Regrowth of the Rat Biliary Tree After $70 \%$ Partial Hepatectomy Is Coupled to Increased Secretin-Induced Ductal Secretion
}

\author{
GENE LESAGE, SHANNON S. GLASER, SIDDESWAR GUBBA, WILLIE E. ROBERTSON, \\ JO LYNNE PHINIZY, JOHN LASATER, REBECCA E. D. RODGERS, \\ and GIANFRANCO ALPINI \\ Department of Internal Medicine, Scott \& White Hospital, and Texas A\&M University Health Science Center, College of Medicine, Temple, \\ Texas
}

Background \& Aims: After partial hepatectomy, liver regeneration occurs with the return of hepatocyte mass to normal. Limited data exist regarding the renewal of the biliary tree after partial hepatectomy. This study tested the hypothesis that, after partial hepatectomy, the biliary tree regenerates by proliferation of the remaining cholangiocytes, leading to an increase in secretin-induced ductal bile secretion. Methods: After $70 \%$ partial hepatectomy, cholangiocyte proliferation was assessed in situ by morphometric analysis and in vitro by measurement of ${ }^{3} \mathrm{H}$-thymidine incorporation. Ductal secretion was estimated by measurement of secretin receptor gene expression and adenosine $3^{\prime}, 5^{\prime}$ cyclic monophosphate (cAMP) levels in vitro and by the effect of secretin on ductal bile secretion in vivo. Results: DNA synthesis was undetectable in control cholangiocytes, increased and peaked at day 3 after partial hepatectomy, and returned to normal by day 28 . Morphometric analysis showed regrowth of the biliary tree beginning at day 1 with restoration by day 10 . The expression of secretin receptor gene and secretininduced cAMP levels and secretin-induced bicarbonaterich choleresis increased during the period of bile duct renewal. Conclusions: After partial hepatectomy, the increase in secretin-induced ductal bile secretion observed during bile duct renewal results from proliferation of remaining cholangiocytes.

$\mathbf{T}$ The liver is comprised of two types of epithelia: (1) hepatocytes, which account for as much as $60 \%$ of the nucleated liver population, ${ }^{1}$ and (2) intrahepatic bile duct epithelial cells or cholangiocytes, which line the intrahepatic biliary tree and represent only 3\%-5\% of the total hepatic population. ${ }^{2-4}$ Cholangiocytes modify bile of canalicular origin by a series of absorptive and secretory processes. ${ }^{2-10} \mathrm{~A}$ number of gastrointestinal hormones, including secretin, modify ductal secretion of water and anions. ${ }^{3-8}$ Secretin enhances ductal secretory activity by interaction with specific receptors on cholan- giocytes, which causes an increase in intracellular adenosine $3^{\prime}, 5^{\prime}$-monophosphate (cAMP) levels. ${ }^{6-8}$ Increased intracellular cAMP levels lead to activation of $\mathrm{Cl}^{-}$channels ${ }^{9,10}$ and $\mathrm{Cl}^{-} / \mathrm{HCO}_{3}{ }^{-}$exchanger activity, ${ }^{5,11}$ which results in the secretin-induced bicarbonate-rich choleresis. $^{2,8}$

In normal liver, cholangiocytes have low basal DNA synthesis. ${ }^{12,13}$ However, cholangiocytes markedly proliferate in a number of experimental models of cholestasis. ${ }^{2,3,8,14-23}$ Three types of cholangiocyte proliferation (typical, atypical, and oval cell proliferation) have been defined. ${ }^{2,3,14-23}$ Typical cholangiocyte proliferation is observed after bile duct ligation (BDL), $\alpha$-naphthylisothiocyanate (ANIT) feeding, or combined BDL/furan treatment and results in ductal proliferation confined to portal areas. $^{2,3,14-16,18,21-23}$ Atypical cholangiocyte proliferation is observed in prolonged cholestatic liver diseases such as primary sclerosing cholangitis and is characterized by irregular proliferation of bile ducts sprouting into lobular regions. ${ }^{3,17,19,20}$ Oval cell proliferation occurs in the early stages of chemically induced hepatocarcinogenesis s $^{3,18,22}$ and is characterized by a disorganized proliferation of ductal structures with a poorly defined lumen. Cholangiocyte proliferation after BDL, for example, is closely associated with an increase in (1) secretin receptor (SR) gene expression ${ }^{24}$ and secretin-induced cAMP levels in vitro $^{6,8}$ and (2) secretin-induced bicarbonate-rich choleresis in vivo. ${ }^{2,8,16}$

In response to resection, the liver has the capacity to regenerate back to its original size. ${ }^{25-27}$ Although all cell types in rat liver may proliferate after $70 \%$ partial hepatectomy, most studies have focused on the role of hepatocytes in this regenerative model. ${ }^{25-27}$ Previous re-

Abbreviations used in this paper: ANIT, $\alpha$-naphthylisothiocyanate; BDL, bile duct ligation; CK-19, cytokeratin 19; GGT, $\gamma$-glutamyl transpeptidase; SR, secretin receptor.

(C) 1996 by the American Gastroenterological Association 0016-5085/96/\$3.00 
ports $^{28-31}$ have shown that, after partial hepatectomy, the regrowth of the intrahepatic biliary tree occurs through proliferation of remaining cholangiocytes. However, these studies do not address the contribution of remaining cholangiocytes to ductal bile secretion after partial hepatectomy using physiological relevant markers of cholangiocyte secretion (e.g., SR gene expression, secretin-stimulated cAMP levels, and secretin-induced choleresis), as we accomplished in these studies.

To begin to address the mechanisms regulating the regrowth of the biliary tree after partial hepatectomy at different intervals (i.e., 1, 3, 6, and 12 hours and 1, 3, $5,7,10,14,21$, and 28 days), we studied (1) the extent of cholangiocyte proliferation by morphometric analysis, (2) the effect of secretin on both bile secretion and bicarbonate excretion in vivo, and (3) DNA synthesis and the molecular and functional expression of SR in cholangiocyte preparations isolated from control rats and from rats at serial intervals after partial hepatectomy. Because of the peculiar characteristics of cholangiocytes (e.g., dormancy in normal state and prolonged $G_{1}$ phase compared with hepatocytes), ${ }^{12,13,31,32}$ we hypothesized that, after partial hepatectomy, cholangiocytes would return to a normal quiescent basal state later (i.e., 28 days) than that observed in hepatocytes (i.e., $10-14$ days). ${ }^{25-27}$

\section{Materials and Methods}

\section{Animal Model}

Male Fisher 344 rats $(75-100 \mathrm{~g})$ were purchased from Charles River (Wilmington, MA), maintained in a temperature-controlled environment $\left(20-22^{\circ} \mathrm{C}\right)$ with a 12 -hour lightdark cycle, and fed ad libitum with standard rat chow. In our studies, we used normal rats and rats at different intervals after partial hepatectomy (i.e., 1, 3, 6, and 12 hours and 1, 3, 5, $7,10,14,21$, and 28 days). After administration of isoflurane/ oxygen anesthesia, $70 \%$ partial hepatectomy was performed as previously described. ${ }^{33}$ Before each experiment (e.g., liver tissue collection for morphometric analysis, liver perfusion for cell isolation, or surgery preparation for bile collection), rats were anesthetized with pentobarbital $(50 \mathrm{mg} / \mathrm{kg}$ intraperitoneally). When necessary, the animals were killed with an overdose of pentobarbital (200 mg/kg intraperitoneally). In all animals used ( $\mathrm{n}=20$ ), both wet liver weight and wet liver weight to body weight ratio were determined.

\section{Materials}

Reagents were purchased from Sigma Chemical Co. (St. Louis, MO) unless otherwise indicated. The pGEM $4 \mathrm{Z}$ vector was obtained from Promega Corp. (Madison, WI). Porcine secretin was purchased from Peninsula (Belmont, CA). The mouse anti-cytokeratin 19 (CK-19) antibody was purchased from Amersham (Arlington Heights, IL). The secondary antibody, a biotinylated horse anti-mouse immunoglobulin $\mathrm{G}$ that was rat adsorbed, was obtained from Vector Laboratories Inc. (Burlingame, CA). Cel-Tak was purchased from Collaborative Biochem Products (Bedford, MA). Dulbecco's phosphate-buffered saline (PBS) was obtained from Celox (Hopkins, MN).

\section{In Situ Determination of Ductal Mass}

We assessed in situ ductal mass by point count analy$\operatorname{sis}^{34,35}$ by determining the number of ducts, stained for either $\gamma$-glutamyl transpeptidase (GGT) or CK-19 (two cholangiocyte-specific markers), ${ }^{2,3,15,36,37}$ present in each coded section $(n=6)$ and obtained randomly from normal and partial hepatectomy rat livers. Immunohistochemistry for CK-19 was performed as previously described by us. ${ }^{15}$ Briefly, after the blocking of nonspecific binding sites by incubation with $1.5 \%$ normal horse serum, frozen liver sections ( $4-6 \mu \mathrm{m}$ thick) were incubated in a humidified chamber for 2 hours at room temperature with a 1:10 dilution of mouse anti-CK-19 antibody. After several washes with Dulbecco's PBS, the liver sections were incubated in a humidified chamber for 30 minutes at room temperature with a 1:200 dilution of a secondary antibody, a biotin-labeled horse anti-mouse immunoglobulin G rat adsorbed. The final peroxidase product was developed using the substrate 3-amino-9-ethylcarbazole. Histochemistry for GGT in frozen liver sections was performed as previously described. ${ }^{38}$ After light counterstaining with hematoxylin, sections were examined in a coded fashion with a Zeiss microscope. In each liver section, the entire area was examined using multiple photographs taken in a mosaic fashion. From the total number of points over hepatic tissue and the number of points over CK-19- and GGT-positive ducts, we calculated the volume percent of liver occupied by ducts. ${ }^{34,35}$ Intrahepatic bile duct mass was estimated by multiplying volume percent of bile ducts from morphometric data by liver weight, from which the sections were obtained assuming equal density of biliary structures and the remainder of the liver. This technique is identical to the approach of Weibel et al., ${ }^{3,35}$ who used point counting morphometry to estimate the relative volume percent and weight of different cell types or subcellular structures in liver. Point counting analysis ${ }^{34,35}$ has also been applied by us to assess ductal mass in normal rat liver. ${ }^{39}$

\section{Isolation and Phenotypic Characterization of Cholangiocytes From Normal and Partial Hepatectomy Rat Livers}

Cholangiocytes from normal and partial hepatectomy rat livers were isolated by immunoaffinity isolation ${ }^{36,39}$ using a monoclonal antibody ubiquitously expressed by all intrahepatic cholangiocytes. ${ }^{36}$ Briefly, after standard collagenase perfusion, ${ }^{15,36,37}$ a cholangiocyte-enriched fraction (40\%-55\% pure by GGT) was obtained from intact portal tracts as previously described by Ishii et al. ${ }^{36}$ and subsequently purified by immunoaffinity separation. ${ }^{36,39}$ Cell purity was assessed using trypan blue exclusion. The diameter of individual cholangiocytes from control rats and from rats 3 days after partial hepatectomy was determined by computerized image analysis as previously described by us. ${ }^{39}$ Cholangiocyte preparations from normal 
and partial hepatectomy rat livers were also characterized by molecular analysis of CK-19 and albumin messenger RNAs, specific markers of cholangiocytes, ${ }^{3,15}$ and hepatocytes, ${ }^{2,18}$ respectively. We used the ribonuclease protection assay, a very sensitive assay for determining steady-state levels of selected messages (see below). ${ }^{24}$

\section{Measurement of DNA Synthesis}

In cholangiocytes from normal and partial hepatectomy rat livers, DNA synthesis was assessed by ${ }^{3} \mathrm{H}$-thymidine incorporation as previously described. ${ }^{40}$ This approach was recently used by us ${ }^{13}$ to measure DNA synthesis in cholangiocyte subpopulations from BDL rat liver. Briefly, 90 minutes after an intraperitoneal injection of $1 \mu \mathrm{Ci} / \mathrm{g}$ body wt of [methyl]- ${ }^{3} \mathrm{H}$ thymidine $(6.70 \mathrm{Ci} / \mathrm{mmol}$; DuPont New England Nuclear Products, Boston, MA), isolated cholangiocyte preparations from normal and partial hepatectomy rat livers $\left(\approx 2.0 \times 10^{6}\right.$, $\geq 97 \%$ pure) were first treated with $3 \mathrm{~mol} / \mathrm{L} \mathrm{KOH}$ at $37^{\circ} \mathrm{C}$ for 30 minutes and then with a solution containing $15 \%$ trichloroacetic acid and $6 \mathrm{~N} \mathrm{HCl}$ at $4^{\circ} \mathrm{C}$ for 12 hours. After centrifugation at $10,000 \mathrm{~g}$ for 20 minutes at $4^{\circ} \mathrm{C}$, DNA was extracted from the cell pellet with $\mathrm{HClO}_{4}$ at $80^{\circ} \mathrm{C}$ for 15 minutes. After spinning, supernatant was transferred and the radioactivity incorporated into DNA was measured in duplicate. Samples were kept for 12 hours at $4{ }^{\circ} \mathrm{C}$ in the dark to avoid chemiluminescence and counted with a Beckman LS 3801 Liquid Scintillation Counter (Irvine, CA).

\section{Cholangiocyte Gene Expression}

The expression of selected genes in lysates obtained from tissues/organs $(\approx 100 \mathrm{mg})$ and cholangiocytes $(2.0-3.0$ $\times 10^{6}$ ) was assessed by the lysate ribonuclease protection assay kit (Direct Protect; Ambion Inc., Austin, TX) according to the instructions of the vendor. This procedure was previously used to determine steady-state levels of selected genes in other cell systems. ${ }^{41,42}$ The comparability of the cholangiocyte lysates used in this assay was assessed by hybridization with the housekeeping gene cyclophilin. ${ }^{43}$ Antisense riboprobes were transcribed from linearized complementary DNA templates with either $\mathrm{T}_{7}$ or $\mathrm{SP}_{6} \mathrm{RNA}$ polymerase using $\left[\alpha-{ }_{-}^{32} \mathrm{P}\right]$ uridine triphosphate (800 Ci/mmol) (Amersham).

We used the following $\left[{ }^{32} \mathrm{P}\right]$ uridine triphosphate-labeled single-strand antisense riboprobes. A 350-base pair riboprobe, encoding for the message of the rat CK-19 gene, was generated from pBlueScript CK-19 (a gift from A. Quaroni, Ithaca, NY); a 345-base pair riboprobe, encoding for the sequence of the albumin gene, was transcribed from pGEM4Z/albumin 345 (a gift from D. Shafritz, Albert Einstein Hospital, Bronx, NY); a probe 103 base pairs long, encoding sequences complementary to rat cyclophilin messenger RNA, was obtained from Ambion Inc.; and a 318-base pair riboprobe encoding the message for SR was transcribed from pGEM4Z-SR (a gift from Dr. N. F. LaRusso, Mayo Clinic, Rochester, MN).

\section{Intracellular cAMP Levels}

Both basal and secretin-altered intracellular cAMP levels in cholangiocytes from normal and partial hepatectomy rat livers were determined as previously described. ${ }^{6-8,44}$ After purification, each cholangiocyte preparation was incubated for 1 hour at $37^{\circ} \mathrm{C}$ to restore surface proteins damaged by treatment with proteolytic enzymes. ${ }^{7}$ From each fraction, $1.0 \times$ $10^{5}$ cholangiocytes were stimulated with secretin $\left(10^{-7} \mathrm{~mol} /\right.$ L) for 5 minutes at $22^{\circ} \mathrm{C}$. In each experiment, $0.5 \mathrm{mmol} / \mathrm{L}$ 3-isobutylmethylxanthine, a phosphodiesterase inhibitor, was added. After ethanol extraction, basal and agonist-induced cAMP formation was measured by radioimmunoassay using commercial kits (Amersham) according to the instructions supplied by the vendor.

\section{Chloride Bicarbonate Exchanger Activity}

Cholangiocytes were obtained from rats at 3 days after partial hepatectomy and examined for $\mathrm{Cl}^{-} / \mathrm{HCO}_{3}{ }^{-}$exchanger activity. The $\mathrm{Cl}^{-} / \mathrm{HCO}_{3}{ }^{-}$exchanger activity was determined by fluorescence measurements of the rate of intracellular alkalinization in cholangiocytes after the abrupt removal of chloride from the media as previously described by us ${ }^{39}$ and others $^{5,11}$ in cholangiocytes from normal rat liver. Briefly, freshly isolated cholangiocytes were placed on glass coverslips coated with Cel-Tak and then incubated at $37^{\circ} \mathrm{C}$ for 1 hour. Cholangiocytes were then loaded with the $\mathrm{pH}$-sensitive fluorescent dye $2^{\prime}, 7^{\prime}$-bis(carboxyethyl)-5,6-carboxyfluorescein acetoxymethyl ester $(1 \mu \mathrm{mol} / \mathrm{L})$ for 10 minutes at $37^{\circ} \mathrm{C}$ and transferred to a perfusion chamber on the stage of an inverted Nikon fluorescence microscope (Tokyo, Japan) fitted with an Omega Optical (Brattleboro, VT) quantitative fluoroscein filter set. The intracellular $\mathrm{pH}$ of cholangiocytes was measured by alternating excitations of $490 / 440 \mathrm{~nm}$ by a motor-driven rotating filtering wheel (Ludh Electronic Products Ltd., Hawthorne, NY) and by a single photon counting photomultiplier tube (Hamamatsu, Hamamatsu City, Japan). The 490/440 fluorescence intensity ratio was converted to intracellular $\mathrm{pH}$ using a nicergin calibration curve as previously described. ${ }^{45,46}$ The signal-to-background fluorescence ratio, measured as previously described, ${ }^{11}$ exceeded 55 in all experiments. Cholangiocytes were first perfused with Krebs-Henseleit bicarbonate solution ( $\mathrm{pH} 7.4$ ) containing $1 \%$ bovine serum albumin (Calbiochem, La Jolla, CA) with or without secretin $\left(10^{-7} \mathrm{~mol} / \mathrm{L}\right.$ for 5 minutes at $22^{\circ} \mathrm{C}$ ). Then the media $\mathrm{Cl}^{-}$was abruptly replaced with equimolar amounts of gluconate. The $\mathrm{Cl}^{-}$/ $\mathrm{HCO}_{3}{ }^{-}$exchanger activity was determined by both the overall $\mathrm{pH}$ increase and the rate of intracellular $\mathrm{pH}$ increase as previously described. ${ }^{35,46}$

\section{In Vivo Biliary Physiology}

After administration of anesthesia, rats were surgically prepared for bile collection as previously described by us ${ }^{2,16}$ and others. ${ }^{8}$ One jugular vein was incannulated with a PE-50 cannula (Clay-Adams, New York, NY) to infuse either KrebsHenseleit bicarbonate solution or the hormone secretin $\left(10^{-7}\right.$ $\mathrm{mol} / \mathrm{L}$ ) dissolved in Krebs-Henseleit bicarbonate solution. Blood was withdrawn every 10 minutes from one carotid artery (PE-60) to assess the arterial hematocrit, which remained constant $(41 \%-45 \%)$ in all animals during bile collection. The 
rate of fluid infusion was adjusted according to both the rate of bile flow and the value of the arterial hematocrit and ranged from 0.738 to $2.964 \mathrm{~mL} / \mathrm{h}$. Body temperature was monitored with a rectal thermometer (Yellow Springs Instruments, Yellow Springs, $\mathrm{OH}$ ) and maintained at $37^{\circ} \mathrm{C}$ by using a heating pad. When steady-state bile flow was achieved (60-70 minutes from the beginning of bile collection), secretin at $10^{-7} \mathrm{~mol} / \mathrm{L}$ was infused for 30 minutes, followed by a final infusion of Krebs-Henseleit bicarbonate solution for 60 minutes. At the end of bile collection, the animal was killed with an overdose of sedative (200 mg/kg intraperitoneally) and the liver removed and weighed. Throughout the experiment, bile was collected every 10 minutes in preweighed tubes and immediately stored at $-20^{\circ} \mathrm{C}$ before determining bicarbonate concentration. Bile volume was determined by weight, assuming a density of 1.0 $\mathrm{g} / \mathrm{mL}$. Bile flow was expressed as microliters per minute per kilogram body weight. Bicarbonate concentration (measured as total $\mathrm{CO}_{2}$ ) in bile from control and partial hepatectomy rats was determined by a Natelson microgasometer apparatus (Scientific Industries, Bohemia, NY).

\section{Results}

\section{Measurement of Liver Mass}

Liver mass (assessed by measurement of wet liver weight) was markedly reduced by partial hepatectomy as expected and returned to normal between days 7 and 10 (results not shown). Liver weight to body weight ratio was decreased after $70 \%$ partial hepatectomy and returned to control values between days 10 and 14 (results not shown). These results are similar to those of other studies. $^{25,33}$

\section{Histochemistry and Immunohistochemistry of the Intrahepatic Biliary Tree}

Before partial hepatectomy, only $2-3$ bile ducts staining for either GGT or CK-19 were observed per portal area of liver section from control rats (results not shown). In contrast, a marked increase in the number of intrahepatic bile ducts per portal area was seen $1-3$ days after partial hepatectomy (results not shown). The number of bile ducts returned to normal by day 28 after partial hepatectomy. Neither portal inflammation nor peribiliary fibrosis was observed in partial hepatectomy rat livers. Morphometric quantitative measurement of bile ductal volume percent (Figure $1 A$ ) showed a significant increase of bile duct density at days $1-3$ after partial hepatectomy compared with control liver $(0.41 \% \pm$ $0.028 \%$ vs. $0.27 \% \pm 0.051 \%, P<0.05$ by unpaired $t$ test; Figure $1 A$ ). The total mass of the intrahepatic biliary tree, estimated from morphometric studies, increased significantly beginning at day 1 and continued to increase until day 10, at which point it was comparable to control values, indicating complete restoration of the biliary tree
(Figure $1 B$ ). Further increases in bile duct mass 10 days after partial hepatectomy was related to normal liver growth and maturation of the rats.

\section{Characteristics of Cholangiocyte Preparations From Normal and Partial Hepatectomy Rat Livers}

In our laboratory, immunoaffinity purification commonly yields cholangiocyte preparations $\geq 97 \%$ positive for GGT but negative for glucose-6-phosphatase histochemistry (results not shown). Most of the cells contaminating our cholangiocyte preparations were cells of mesenchymal origin, which correlates to our previous studies. ${ }^{15}$ Cell viability was $\geq 98 \%$. No significant $(P>$ $0.05)$ changes in diameter were observed in cholangiocytes from rats 3 days after partial hepatectomy (11.46 \pm 0.27 [mean $\pm \mathrm{SE}]$ ) compared with cholangiocytes from control rats $(12.1 \pm 0.15)$. The data are in agreement with our previous observations ${ }^{2,15,18}$ showing that proliferating cholangiocytes from BDL rat liver have a diameter similar to that of normal cholangiocytes.

\section{Measurement of DNA Synthesis in Cholangiocytes From Normal and Partial Hepatectomy Rat Livers}

Before partial hepatectomy, DNA synthesis, assessed by measurement of ${ }^{3} \mathrm{H}$-thymidine uptake, was virtually absent in control cholangiocytes (Figure 2), a finding that parallels previous studies by us ${ }^{13}$ and others. ${ }^{12}$ After partial hepatectomy, DNA synthesis increased, reached a peak at day 3, and returned to control quiescent values at day 28 (Figure 2). The data are consistent with the hypothesis that remaining cholangiocytes proliferate after partial hepatectomy, thus participating in the restoration of the intrahepatic biliary tree.

\section{In Vitro Molecular Analysis}

As shown in Figure $3 A$, purified cholangiocytes from normal and partial hepatectomy rat livers expressed CK-19 but not albumin messenger RNA (Figure 3A). Cyclophilin, the housekeeping gene, was similarly expressed among purified cholangiocytes (Figure $3 A$ ). In agreement with our previous studies, ${ }^{24}$ the message for the SR gene was detected in control cholangiocytes. Parallel to changes in DNA synthesis, SR gene expression increased at day 1 after partial hepatectomy, reached a maximum at days 3-5 (an approximately sevenfold increase), and declined to control levels at day 28. Densitometry analysis of selected messages is shown in Figure $3 B$. 

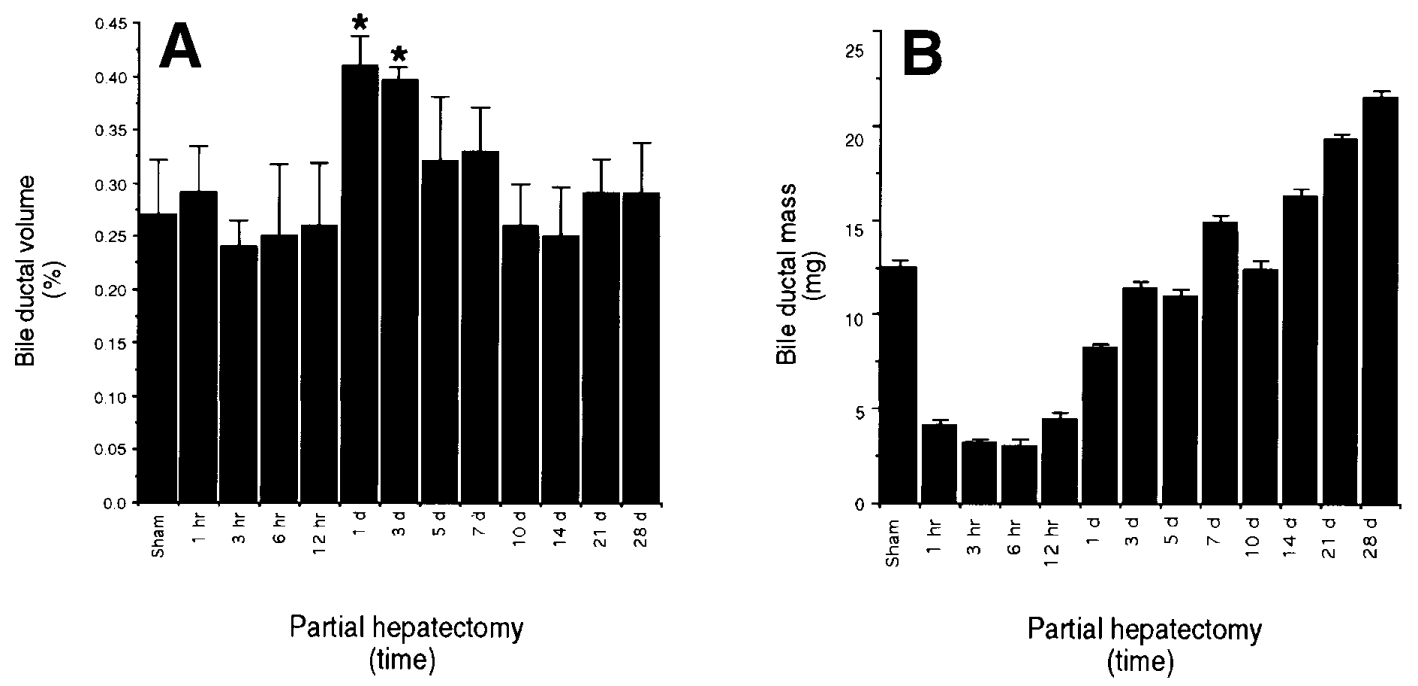

Figure 1. $(A)$ The volume density of bile ductal structures in livers from normal and partial hepatectomy rats was determined by morphometric analysis by determining the number of ducts stained for either GGT or CK-19 present in frozen sections $(n=6)$ obtained randomly from normal and partial hepatectomy rat livers. (B) From volume density and liver weights, bile duct mass was estimated. A transient increase of duct density is observed at days 1 and 3, coinciding with the histochemical staining for GGT (results not shown). Bile duct mass, reduced by partial hepatectomy, is restored by day 10 . Statistical analysis was performed by unpaired $t$ test. $* P<0.05$.

\section{Intracellular Levels of cAMP}

cAMP formation was determined because intracellular levels are closely coupled to proliferative and secretory activity in cholangiocytes ${ }^{6,8}$ and other cell types. ${ }^{47,48}$ Before partial hepatectomy, basal cAMP for-

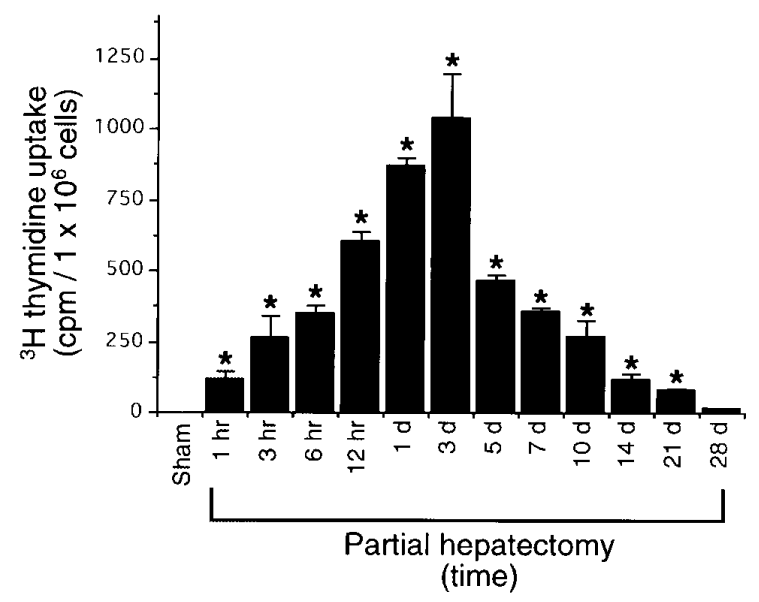

Figure 2. Ninety minutes after an intraperitoneal injection of $1 \mu \mathrm{Ci}$ / $\mathrm{g}$ body wt of [methyl]- ${ }^{3} \mathrm{H}$-thymidine, the radioactivity incorporated into DNA was measured in preparations of cholangiocytes $\left(\approx 2.0 \times 10^{6}\right.$ cells; $\geq 97 \%$ pure) obtained by immunoaffinity separation ${ }^{36,39}$ from normal and partial hepatectomy rat livers. DNA synthesis was absent in normal cholangiocytes. Note that, after partial hepatectomy, DNA synthesis increased, reached a peak at day 3 , and returned to control quiescent values at day $28 . * P<0.05$ compared with control cholangiocytes. Statistical analysis was performed by unpaired $t$ test. mation in cholangiocytes $\left(14.32 \pm 0.8 \mathrm{fmol} / 1 \times 10^{5}\right.$ cells; Figure 4) was similar to that reported in other studies. $^{7}$ After partial hepatectomy, basal cAMP levels markedly increased in cholangiocytes, reached a peak at day $5\left(28.07 \pm 0.7 \mathrm{fmol} / 1 \times 10^{5}\right.$ cells; $P<0.05$ by unpaired $t$ test), and returned to values similar to that of control cholangiocytes at day 28 (Figure 4). In control cholangiocytes, the increase in secretin-induced cAMP levels $\left(+9.72 \pm 1.9 \mathrm{fmol} / 1 \times 10^{5}\right.$ cells; Figure 4) was similar to that of other studies. ${ }^{7}$ Secretin-induced cAMP levels in cholangiocytes from partial hepatectomy rat livers were increased in parallel to SR gene expression, higher as early as at 1 hour after partial hepatectomy, peaked between days 5 and $7(+21.3 \pm 1.1$ and 25.7 $\pm 6.2 \mathrm{fmol} / 1 \times 10^{5}$ cells, respectively; $P<0.05$ by unpaired $t$ test), and then gradually returned to control values $\left(+8.89 \pm 1.9 \mathrm{fmol} / 1 \times 10^{5}\right.$ cells $)$ at day 28 (Figure 4).

\section{Chloride Bicarbonate Exchanger Activity}

To further address if secretory activity of cholangiocytes was enhanced after partial hepatectomy, we measured $\mathrm{Cl}^{-} / \mathrm{HCO}_{3}{ }^{-}$exchanger activity of individual cholangiocytes isolated from control rats and rats 3 days after partial hepatectomy (Figure 5 and Table 1). The maximum rate of increase of intracellular $\mathrm{pH}$ and the overall intracellular $\mathrm{pH}$ increase after the abrupt removal of $\mathrm{Cl}^{-}$from the media, indices of $\mathrm{Cl}^{-} / \mathrm{HCO}_{3}{ }^{-}$exchanger activity, were measured in cholangiocytes from control and partial hepatectomy rat livers in the presence and the absence of $10^{-7} \mathrm{~mol} / \mathrm{L}$ secretin (Figure 5 and Table 
1). In single experiments, shown in Figure 5, secretin enhanced the rate of intracellular alkalinization in cholangiocytes from partial hepatectomy livers on day 3 (Figure $5 D$ ) to a greater degree compared with control cholangiocytes (Figure $5 C$ ). The maximum rate of alkalinization was enhanced by secretin in cholangiocytes from partial hepatectomy rat livers (secretin, $0.34 \pm$ 0.08; basal, $0.14 \pm 0.04 ; P<0.05$ ) compared with control cholangiocytes (secretin, $0.22 \pm 0.06$; basal, $0.11 \pm 0.04 ; P<0.05$ ) (see Table 1 ). In the absence of secretin, after $\mathrm{Cl}^{-}$removal, the rate of the overall increase in intracellular $\mathrm{pH}$ in cholangiocytes from partial hepatectomy rat liver was not statistically different with respect to control cholangiocytes $(P>0.05$ by
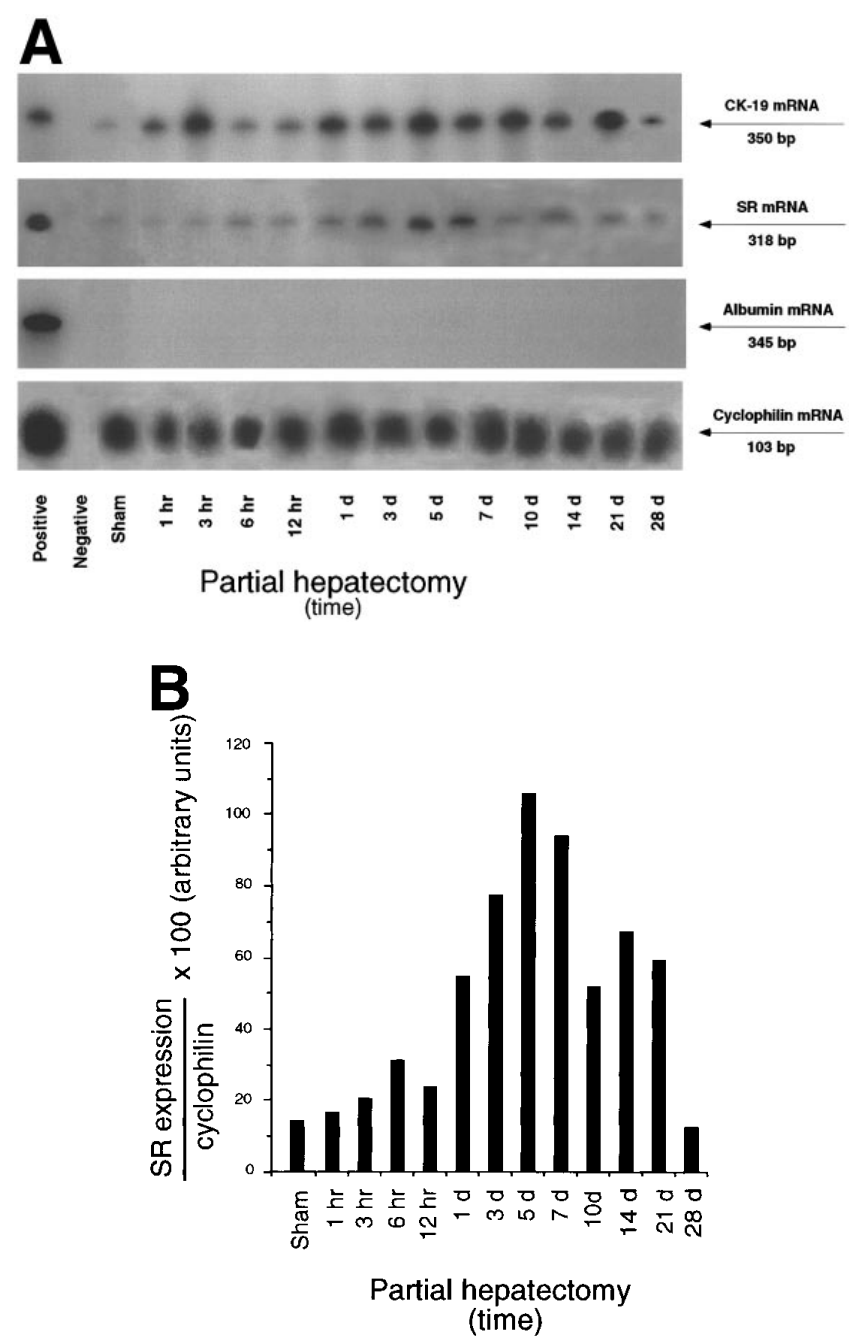

Figure 3. (A) The expression of selected messages was determined by direct ribonuclease protection assay using cell lysate samples each containing $4.50 \times 10^{5}$ pure cholangiocytes obtained from control rats and rats at different intervals after partial hepatectomy. The comparability of the cholangiocyte lysates used was assessed by hybridization for cyclophilin, the housekeeping gene. (B) After exposure for 24 hours at $-70^{\circ} \mathrm{C}$, autoradiograms were quantified by densitometry. unpaired $t$ test). These data indicate that partial hepatectomy is associated with increased secretin-induced $\mathrm{Cl}^{-}$/ $\mathrm{HCO}_{3}{ }^{-}$exchanger activity in individual cholangiocytes.

\section{In Vivo Effect of Secretin on Ductal Bile Flow and Bicarbonate Excretion}

During the first 24 hours after partial hepatectomy, before the onset of DNA synthesis, ${ }^{25}$ both basal bile flow and biliary bicarbonate output were markedly reduced (an approximate 2.0-fold decrease) as expected, returning to control values by day 3 and remaining slightly higher from days 5 to 28 after partial hepatectomy (Figure $6 A$ and $B$ and Table 2). Before partial hepatectomy, secretin had no effect on either bile flow (Figure $6 \mathrm{~A}$ and Table 2) or bicarbonate output (Figure $6 B$ and Table 2) as expected. ${ }^{2,8,16}$ Within the first 12 hours after partial hepatectomy, secretin produced no significant changes in either ductal bile secretion (Figure $6 \mathrm{~A}$ and Table 2) or bicarbonate output (Figure $6 B$ and Table 2). In contrast, secretin significantly increased both bile flow $\left(+23.1 \pm 0.9 \mu \mathrm{L} \cdot \mathrm{min}^{-1} \cdot \mathrm{kg}\right.$ body $\mathrm{wt}^{-1}$ vs. basal value, $P<0.05$ by unpaired $t$ test; Figure $6 \mathrm{~A}$ and Table 2) and bicarbonate output $(+1.12 \pm 0.1$ $\mu \mathrm{Eq} \cdot \min ^{-1} \cdot \mathrm{kg}$ body $\mathrm{wt}^{-1}$ vs. basal value, $P<0.05$ by unpaired $t$ test; Figure $6 B$ and Table 2) from days 1 to 5 after partial hepatectomy before gradually declining to normal values at day 28 after partial hepatectomy. Our studies of biliary physiology are summarized in Table 2.

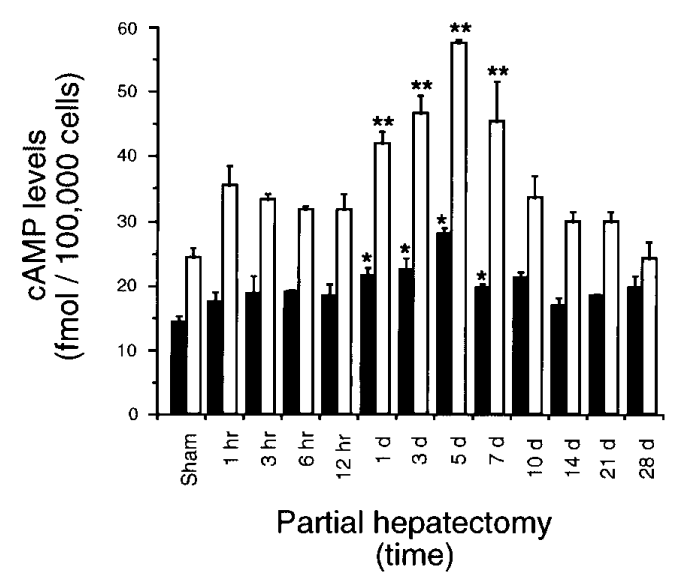

Figure 4. Basal and secretin-induced cAMP levels in cholangiocytes isolated from control and partial hepatectomy rat livers. *Basal cAMP levels of cholangiocytes from partial hepatectomy rat livers differing from basal cAMP levels of cholangiocytes isolated from control rats are indicated by $P<0.05$. **Secretin-induced cAMP levels of cholangiocytes from rats that have undergone partial hepatectomy differing from secretin-induced cAMP levels from control cholangiocytes are indicated by $P<0.05$. Statistical analysis was performed by unpaired $t$ test. Data are expressed as the means \pm SE for $\geq 4$ rats. $\mathbf{\square}$, Basal; $\square, 10^{-7} \mathrm{~mol} / \mathrm{L}$ secretin. 

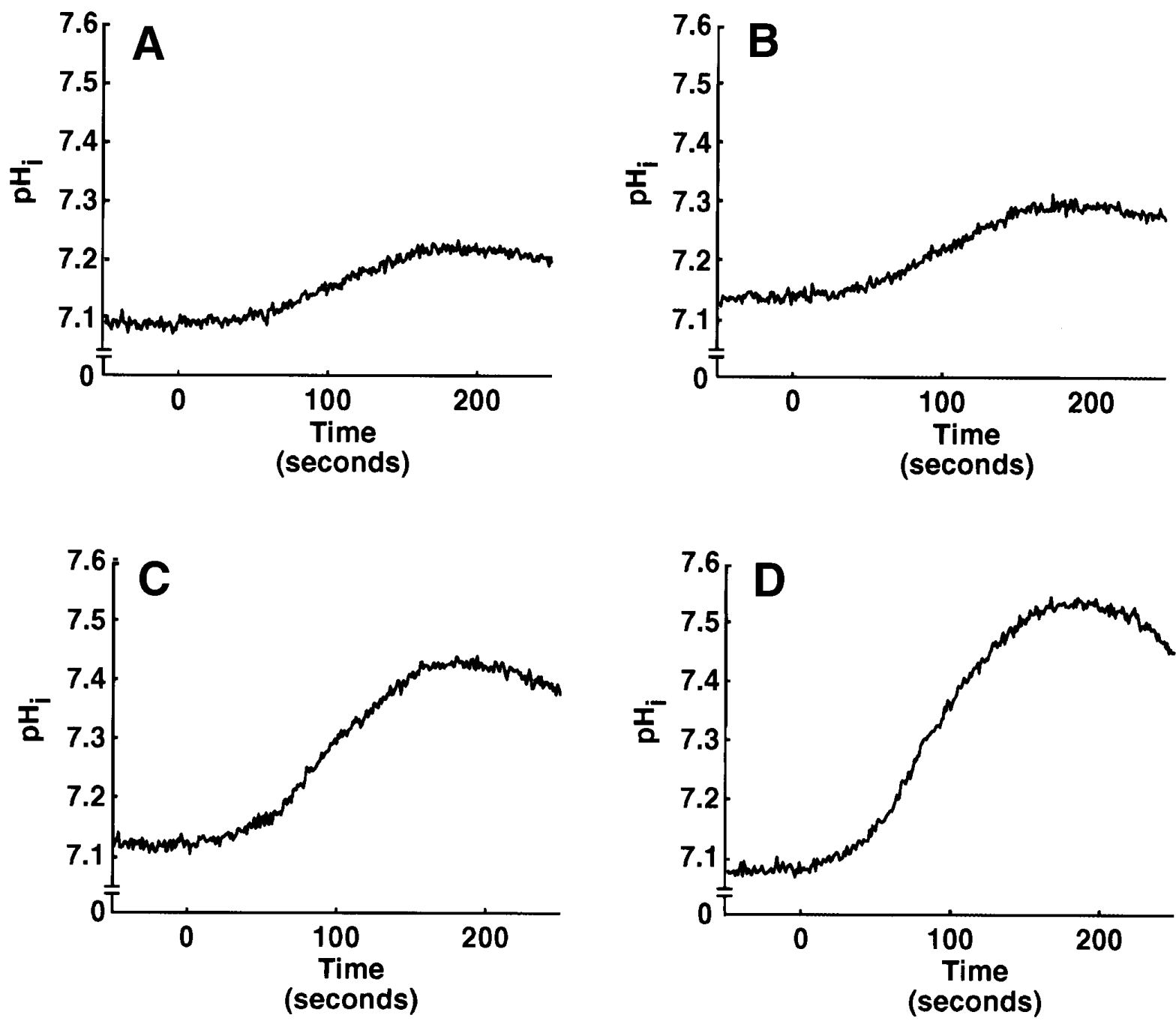

Figure 5. Effects of secretin $\left(10^{-7} \mathrm{~mol} / \mathrm{L}\right)$ on $\mathrm{Cl}^{-} / \mathrm{HCO}_{3}{ }^{-}$exchanger activity in cholangiocytes isolated from $(A$ and $C)$ control rats and $(B$ and D) rats at 3 days after partial hepatectomy. The $\mathrm{Cl}^{-} / \mathrm{HCO}_{3}{ }^{-}$exchanger activity was determined by fluorescence measurements of intracellular $\mathrm{pH}$ in cholangiocytes during the abrupt removal of $\mathrm{Cl}^{-}$as described in Materials and Methods. Although the maximum rate of change of intracellular $\mathrm{pH}$ was significantly increased by $10^{-7} \mathrm{~mol} / \mathrm{L}$ secretin in cholangiocytes from both $(A$ and $C)$ control and $(B$ and $D)$ partial hepatectomy rat livers, secretin-enhanced $\mathrm{Cl}^{-} / \mathrm{HCO}_{3}{ }^{-}$exchanger activity was significantly greater in cholangiocytes from partial hepatectomy livers compared with control cholangiocytes. $(A)$ Normal, $(C)$ normal plus secretin, $(B)$ partial hepatectomy, and $(D)$ partial hepatectomy plus secretin.

\section{Correlation Between Cholangiocyte Proliferation and Secretin-Induced Ductal Bile Secretion After Partial Hepatectomy}

We found a significant correlation $(r=0.6 ; P<$ 0.05 ) between secretin-induced choleresis and cholangiocyte proliferation assessed by ${ }^{3} \mathrm{H}$-thymidine uptake into cholangiocytes (Figure 7). Thus, with the regrowth of the biliary tree after partial hepatectomy, there is close coupling of enhanced ductal secretory activity and cholangiocyte proliferation. Similarly, significant correlations were found between ${ }^{3} \mathrm{H}$-thymidine uptake and both intracellular secretin-induced cAMP levels and SR gene expression ( $r=0.6$ and $r=0.7$, respectively; $P<0.05$; results not shown).

\section{Discussion}

The major findings of these studies relate to the increased proliferative and secretory activity of rat cholangiocytes after $70 \%$ partial hepatectomy. The data provide conclusive evidence that cholangiocytes respond physiologically to partial hepatectomy and participate in the regrowth of the biliary tree. In situ, partial hepatectomy is associated with a transient increase in the density of bile ducts in the liver with the histological appearance of typical cholangiocyte proliferation, which peaks at days $1-3$, indicating the beginning of cholangiocyte replication. Morphometric studies showed restoration of the biliary tree by day 10 . In vitro, DNA synthesis (assessed by measurement of ${ }^{3} \mathrm{H}$-thymidine incorporation) was ab- 
Table 1. Effect of Secretin on $\mathrm{Cl}^{-} / \mathrm{HCO}_{3}{ }^{-}$Exchanger Activity in Cholangiocytes From Normal and Partial Hepatectomy Rat Livers

\begin{tabular}{|c|c|c|c|c|}
\hline & \multicolumn{2}{|c|}{ Normal } & \multicolumn{2}{|c|}{ Partial hepatectomy } \\
\hline & Control & Secretin & Control & Secretin \\
\hline $\begin{array}{l}\text { Basal intracellular } \mathrm{pH} \\
\mathrm{Cl}^{-} \text {removal intracellular } \mathrm{pH}\end{array}$ & $7.08 \pm 0.06$ & $7.10 \pm 0.06$ & $7.11 \pm 0.07$ & $7.14 \pm 0.06$ \\
\hline $\begin{array}{l}\text { maximum change } \\
\text { Intracellular pH maximum }\end{array}$ & $0.18 \pm 0.05$ & $0.30 \pm 0.07^{a}$ & $0.21 \pm 0.07$ & $0.48 \pm 0.11^{a}$ \\
\hline rate of change per minute & $0.11 \pm 0.04$ & $0.22 \pm 0.06^{a}$ & $0.14 \pm 0.04$ & $0.34 \pm 0.08^{a, b}$ \\
\hline
\end{tabular}

NOTE. The $\mathrm{Cl}^{-} / \mathrm{HCO}_{3}{ }^{-}$exchanger activity was assessed in pure cholangiocytes isolated from normal and 3-day partial hepatectomy rat livers by the maximal intracellular $\mathrm{pH}$ increase associated with acute $\mathrm{Cl}^{-}$removal and the maximal rate of intracellular $\mathrm{pH}^{\mathrm{increase}}$ after $\mathrm{Cl}^{-}$as described in Materials and Methods. Secretin at $10^{-7} \mathrm{~mol} / \mathrm{L}$ was added to perfusate in the presence of $1 \%$ in serum bovine albumin; in control experiments, only albumin was added. Data are expressed as the means \pm SE of 6 experiments.

${ }^{a}$ Significantly greater than controls $(P<0.05)$.

${ }^{b}$ Significantly greater than secretin-treated normal cholangiocytes $(P<0.05)$.

sent in control cholangiocytes but increased after partial hepatectomy, reached its peak at day 3 , and returned to normal values at day 28. In parallel to DNA synthesis and the period of regrowth of the biliary tree, there was a transient increase in SR gene expression, secretininduced cAMP levels, and $\mathrm{Cl}^{-} / \mathrm{HCO}_{3}{ }^{-}$exchanger activity in vitro and secretin-induced choleresis and bicarbonate output in vivo before they returned to control values at day 28. Taken together, the data indicate that after partial hepatectomy, there is an increase in secretin-stimulated ductal bile secretion attributable to increased secretory activity per individual cholangiocyte, and this increased secretory activity is closely coupled to the rate of ductal regrowth by proliferation of remaining cholangiocytes.
In the normal state, there seems to be a low basal turnover of cholangiocytes. ${ }^{2,12,13}$ In contrast, cholangiocytes proliferate in a group of benign and malignant human liver diseases called cholangiopathies, including primary biliary cirrhosis, primary sclerosing cholangitis, and cholangiocarcinoma. ${ }^{3}$ In animal models of cholestasis, cholangiocyte proliferation is associated with a number of pathological perturbations, including BDL $^{2,3,8,15,16,18,21}$ and ANIT feeding. ${ }^{3,16,18}$ In the present studies, we examined whether cholangiocytes contribute to the regrowth of the biliary tree after partial hepatectomy and if restoration of the biliary tree by remaining cholangiocytes occurs through a process similar to ductal hyperplasia observed after BDL. ${ }^{2,8,15,16}$ Our in situ morphometric analysis (Figure $1 A$ and $B$ ) supports the con-
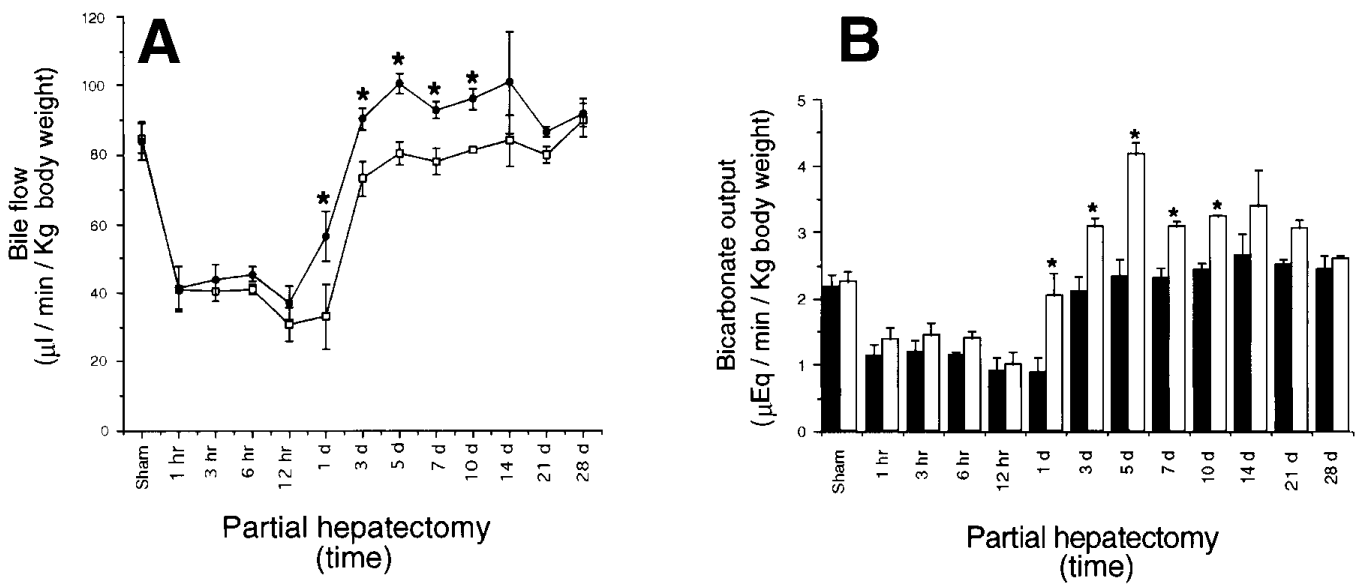

Figure 6. Effect of secretin $\left(10^{-7} \mathrm{~mol} / \mathrm{L}\right)$ on both $(A)$ ductal bile flow and $(B)$ biliary bicarbonate excretion in sham-operated rats and rats at different intervals after partial hepatectomy. $(A)$ Bile was collected every 10 minutes and expressed as microliters per minute per kilogram body weight. Secretin was infused for 30 minutes through a jugular vein after a 60-minute equilibration infusion period with Krebs-Henseleit bicarbonate solution. $* P<0.05$ vs. basal values by unpaired $t$ test. Data are expressed as the means $\pm \mathrm{SE}$ for $\geq 3$ rats. $\square$, Basal; $\bullet, 10^{-7}$ $\mathrm{mol} / \mathrm{L}$ secretin. $(B)$ Bile collected every 10 minutes in preweighed tubes and immediately stored at $-20^{\circ} \mathrm{C}$ before determining bicarbonate concentration. Bicarbonate concentrations (measured as total $\mathrm{CO}_{2}$ ) were determined by a Natelson microgasometer apparatus. Data were expressed as microequivalent per minutes per kilogram body weight. $\mathbf{\square}$, Basal; $\square, 10^{-7} \mathrm{~mol} / \mathrm{L}$ secretin. *Secretin-stimulated biliary bicarbonate excretion differing from basal values are indicated by $P<0.05$. Statistical analysis was performed by unpaired $t$ test. 
Table 2. Bile Flow and Composition in Normal and Partial Hepatectomy Rat Livers

\begin{tabular}{|c|c|c|c|c|c|c|}
\hline \multirow[b]{2}{*}{ Treatment } & \multicolumn{2}{|c|}{ Bile flow } & \multicolumn{4}{|c|}{ Bicarbonate in bile } \\
\hline & $\begin{array}{c}\text { Basal } \\
\left(\mu L \cdot \min ^{-1} \cdot\right. \\
\left.k g \text { body } w t^{-1}\right)\end{array}$ & $\begin{array}{c}\text { Secretin } \\
\left(\mu L \cdot \min ^{-1} \cdot\right. \\
\left.\text { kg body } w t^{-1}\right)\end{array}$ & $\begin{array}{c}\text { Basal } \\
(m E q / L)\end{array}$ & $\begin{array}{l}\text { Secretin } \\
(m E q / L)\end{array}$ & $\begin{array}{c}\text { Basal } \\
\left(\mu E q \cdot \mathrm{min}^{-1} \cdot\right. \\
\left.\mathrm{kg} \text { body } w t^{-1}\right)\end{array}$ & $\begin{array}{c}\text { Secretin } \\
\left(\mu E q \cdot \min ^{-1} \cdot\right. \\
\left.k g \text { body } w t^{-1}\right)\end{array}$ \\
\hline Control & $84.9 \pm 4.2$ & $84.0 \pm 5.5$ & $25.8 \pm 0.46$ & $26.8 \pm 0.92$ & $2.18 \pm 0.16$ & $2.25 \pm 0.14$ \\
\hline $\mathrm{pH}$ at 1 hour & $41.1 \pm 6.4$ & $41.4 \pm 6.3$ & $27.9 \pm 2.1$ & $30.7 \pm 1.6$ & $1.14 \pm 0.17$ & $1.39 \pm 1.6$ \\
\hline $\mathrm{pH}$ at 3 hours & $40.5 \pm 2.8$ & $43.7 \pm 4.2$ & $29.4 \pm 2.41$ & $33.2 \pm 2.48$ & $1.20 \pm 0.18$ & $1.45 \pm 0.19$ \\
\hline $\mathrm{pH}$ at 6 hours & $40.9 \pm 1.4$ & $45.5 \pm 2.2$ & $28.0 \pm 0.98$ & $30.7 \pm 1.00$ & $1.14 \pm 0.06$ & $1.40 \pm 0.11$ \\
\hline $\mathrm{pH}$ at 12 hours & $30.9 \pm 4.8$ & $37.2 \pm 4.9$ & $28.9 \pm 2.09$ & $27.0 \pm 1.34$ & $0.89 \pm 0.21$ & $1.00 \pm 0.18$ \\
\hline $\mathrm{pH}$ at 1 day & $33.1 \pm 9.3$ & $56.3 \pm 7.2^{a}$ & $27.7 \pm 1.18$ & $31.7 \pm 1.72^{a}$ & $0.89 \pm 0.23$ & $2.04 \pm 0.33^{a}$ \\
\hline $\mathrm{pH}$ at 3 days & $73.1 \pm 5.2$ & $90.4 \pm 3.0^{a}$ & $28.8 \pm 0.77$ & $36.1 \pm 0.29^{a}$ & $2.10 \pm 0.23$ & $3.08 \pm 0.13^{a}$ \\
\hline $\mathrm{pH}$ at 5 days & $80.5 \pm 3.3$ & $100.7 \pm 2.7^{a}$ & $29.0 \pm 0.68$ & $41.3 \pm 1.54^{a}$ & $2.34 \pm 0.25$ & $4.16 \pm 0.19^{a}$ \\
\hline $\mathrm{pH}$ at 7 days & $78.1 \pm 3.9$ & $93.2 \pm 2.4^{a}$ & $29.5 \pm 0.69$ & $33.2 \pm 0.32^{a}$ & $2.42 \pm 0.11$ & $3.09 \pm 0.07^{a}$ \\
\hline $\mathrm{pH}$ at 10 days & $81.4 \pm 3.9$ & $96.3 \pm 3.2^{a}$ & $30.8 \pm 1.23$ & $33.6 \pm 1.35$ & $2.63 \pm 0.34$ & $3.23 \pm 0.03^{a}$ \\
\hline $\mathrm{pH}$ at 14 days & $84.2 \pm 7.6$ & $100.9 \pm 14$ & $31.3 \pm 0.79$ & $33.5 \pm 0.52$ & $2.51 \pm 0.08$ & $3.39 \pm 0.54$ \\
\hline $\mathrm{pH}$ at 21 days & $80.1 \pm 2.5$ & $86.7 \pm 1.5$ & $31.5 \pm 0.41$ & $34.6 \pm 0.73$ & $2.80 \pm 0.23$ & $3.04 \pm 0.14$ \\
\hline $\mathrm{pH}$ at 28 days & $90.1 \pm 4.9$ & $92.3 \pm 4.1$ & $32.2 \pm 0.94$ & $33.6 \pm 1.40$ & $2.30 \pm 0.15$ & $3.09 \pm 0.04$ \\
\hline
\end{tabular}

NOTE. Values are expressed as the means $\pm \mathrm{SE}$ for $\geq 3$ rats and were obtained at steady-state conditions of bile flow. After an equilibration period of 60 minutes with Krebs-Henseleit bicarbonate solution, secretin was infused via a jugular vein for 30 minutes at $10^{-7}$ mol/L.

a Values differing from basal are indicated by $P<0.05$.

cept that the regrowth of intrahepatic bile ducts after partial hepatectomy occurs through typical cholangiocyte proliferation with a significant increase in the density of ductal structures at days $1-3$, thus indicating a transient burst of proliferation of preexisting cholangiocytes. However, in contrast to $\mathrm{BDL},{ }^{2,3,8,14,16}$ cholangiocyte proliferation observed after partial hepatectomy is transitory because cholangiocyte proliferation ceases before 28 days. The arrest of ductal growth may be induced by either cessation of cholangiocyte proliferation attributable to a decrease in the concentration of specific circulating growth factors ${ }^{25}$ or apoptosis. ${ }^{49,50}$ Indeed, in support of

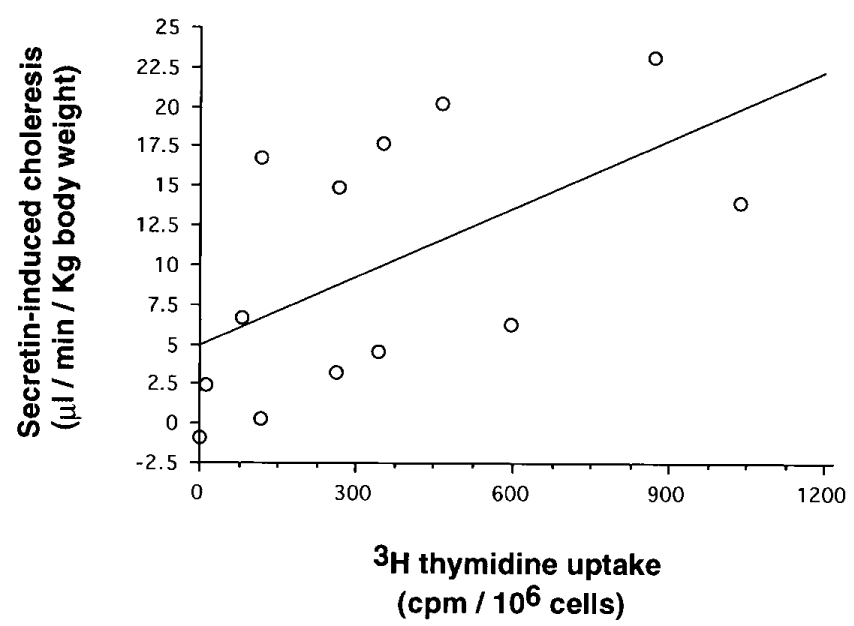

Figure 7. Regression analysis between ${ }^{3} \mathrm{H}$-thymidine $\left(\mathrm{cpm} / 1 \times 10^{6}\right.$ cholangiocytes) and secretin-induced choleresis (microliters per minute per kilogram body weight). Note that, after partial hepatectomy, a significant relationship $(r=0.60 ; P<0.05)$ exists in cholangiocytes between DNA synthesis and secretin-induced choleresis. the latter concept, a number of studies ${ }^{49,50}$ have shown that regression of cholangiocyte hyperplasia after removal of the proliferative stimulus may occur through apoptosis.

Methods to isolate pure cholangiocyte preparations were required to study proliferative and secretory capacity of cholangiocytes in these studies. Cholangiocytes from normal and proliferating rat livers have been purified by a number of techniques, including isopyknic centrifugation $^{51}$ and counterflow elutriation. ${ }^{15,52}$ However, these approaches yielded cholangiocyte preparations with a fair amount of contamination. As a refinement of these approaches, we used a monoclonal antibody specific to membrane components present on all intrahepatic cholangiocytes. ${ }^{36} \mathrm{By}$ this technique, virtually pure preparations of cholangiocytes can be isolated from either normal or proliferating rat liver. ${ }^{24,36,39}$ To establish whether cholangiocytes from partial hepatectomy rat livers retain phenotypes of normal cholangiocytes, we determined the presence of two cholangiocyte-specific markers: GGT by histochemistry (results not shown) and CK-19 by ribonuclease protection assay (Figure $3 A$ ). By molecular analysis of albumin, these studies excluded in our cholangiocyte preparations the presence of hepatocytes (Figure 3A), which represent the major cell population during liver regeneration after partial hepatectomy. ${ }^{25-27}$ Furthermore, these data (Figure 3A) indicate that cholangiocytes isolated after partial hepatectomy retain phenotypes of normal cholangiocytes, a finding consistent with typical cholangiocyte proliferation as seen in BDL. ${ }^{2,15,18}$

To assess the proliferative response of cholangiocytes to partial hepatectomy, we assessed DNA synthesis by 
measurement of ${ }^{3} \mathrm{H}$-thymidine uptake, an approach previously used by us to determine DNA synthesis in cholangiocyte subpopulations from BDL rat liver. ${ }^{13}$ Before partial hepatectomy, DNA synthesis was absent in control cholangiocytes (Figure 2); these results are in agreement with previous reports. ${ }^{12,13}$ After partial hepatectomy, DNA synthesis in cholangiocytes reaches a maximum at 48 hours after the peak of hepatocyte replication, a value similar to that of other reports. ${ }^{25,31,32}$ For example, previous studies from Grisham ${ }^{31}$ and Haber et al., ${ }^{31,32}$ aiming to assess peak DNA synthesis of nonparenchymal cells, showed that DNA replication of nonparenchymal cells occurs approximately $24-36$ hours after the peak of hepatocyte DNA synthesis. However, these studies $^{31,32}$ were performed using in situ autoradiography $^{31}$ or in mixed nonparenchymal cell fraction ${ }^{32}$ (only $3 \%-5 \%$ pure in cholangiocytes) ${ }^{2-4,15,16,37}$ and do not accurately measure the peak of DNA synthesis in pure $(\geq 97 \%)$ preparations of cholangiocytes as we did in the present studies. The discrepancy in the timing of the peaks of DNA synthesis between hepatocytes and cholangiocytes is presumably attributable to a more prolonged G1 phase during the cell cycle of nonparenchymal cells as compared with hepatocytes. ${ }^{25,31,32}$ In agreement with other studies, ${ }^{28-31}$ the data support the concept that cholangiocytes replicate and renew the ductal biliary system in response to partial hepatectomy.

Because cholangiocyte proliferation in both BDL and ANIT-fed rats is associated with increased secretory activity of the biliary tree, we determined SR gene expression, basal and secretin-induced cAMP levels, basal and secretin-induced $\mathrm{Cl}^{-} / \mathrm{HCO}_{3}{ }^{-}$exchanger activity, and the in vivo effect of secretin on both ductal bile secretion and bicarbonate output. The rationale for using secretin as a physiological end point of ductal bile secretion is based on a number of observations. ${ }^{2,3,5-8,11,24}$ We have shown $^{24}$ that, in the liver, SR messenger RNA is uniquely expressed by cholangiocytes and is up-regulated after BDL. Also, secretin induces cAMP formation ${ }^{6-8}$ and $\mathrm{Cl}^{-} / \mathrm{HCO}_{3}{ }^{-}$exchanger activity ${ }^{5,11}$ in isolated cholangiocytes. Moreover, selective cholangiocyte proliferation is associated with a marked increase in secretin-induced bicarbonate-rich choleresis in the BDL rat liver. ${ }^{2,3,8,16}$ Our molecular analysis (Figure $3 A$ and $B$ ) shows that SR messenger RNA was present at low levels in control cholangiocytes, which is a finding that correlates with previous studies. ${ }^{24}$ Indeed, low expression of SR by individual cholangiocytes ${ }^{24}$ is believed to explain why secretin produces no changes in bile flow when infused into normal rats. ${ }^{2,8,16}$ As shown in Figure $3 A$ and $B$, SR is up-regulated in individual cholangiocytes from partial hepatectomy rat liver as compared with control cholan- giocytes (Figure $3 A$ and $B$ ) in a fashion similar to that of cholangiocytes from BDL rat liver. ${ }^{24}$ As evidence of increased biological activity of the SR, we found an enhanced physiological responsiveness of cholangiocytes to secretin by increases of secretin-induced intracellular cAMP levels and $\mathrm{Cl}^{-} / \mathrm{HCO}_{3}{ }^{-}$exchanger activity in vitro and bile flow and bicarbonate output in vivo. As shown in Figure 4, basal cAMP levels were markedly elevated in cholangiocytes from partial hepatectomy rat livers. Elevated basal cAMP levels are consistent with cholangiocyte proliferative response because a number of reports ${ }^{47,48}$ indicate that cAMP is a major regulatory determinant of cellular proliferation. As evidence of a tightly regulated process, at completion of regeneration, increased ${ }^{3} \mathrm{H}$-thymidine uptake and SR gene expression, elevated basal and secretin-stimulated cAMP levels, and secretin-stimulated bicarbonate rich choleresis all decrease in parallel 3-5 days after partial hepatectomy, gradually declining to normal values by day 28 . The factors that control these series of closely coupled events remain unknown. There were significant correlations between cholangiocyte proliferation (assessed by ${ }^{3} \mathrm{H}$-thymidine uptake) and ductal secretory activity as assessed by secretin-induced choleresis $(r=0.60 ; P<0.05)$ (Figure 7), secretin stimulated cAMP levels $(r=0.60, P<0.05$; results not shown), and SR gene expression $(r=0.70$, $P<0.05$; results not shown).

Our novel studies have physiological and pathophysiological relevance because no information exists with regard to the regulatory mechanisms of the regrowth of the biliary tree after partial hepatectomy under basal and hormone-stimulated conditions. Furthermore, because the partial hepatectomy model is devoid of cholestasis or inflammation as occurs in other models of cholangiocyte proliferation, ${ }^{2,3,8,16}$ it represents an excellent model to study mechanisms of cholangiocyte proliferation. Understanding the mechanisms by which cholangiocytes respond to proliferative perturbations such as partial hepatectomy may increase our knowledge of the cause of human cholestatic liver diseases that affect primarily cholangiocytes, including primary biliary cirrhosis, primary sclerosing cholangitis, and allograft rejection after liver transplantation. Based on the concept of functional cholangiocyte heterogeneity recently developed by us, ${ }^{13,39}$ a direct outgrowth of these studies will be the isolation and characterization of specific cholangiocyte subpopulations involved in the regrowth of the biliary tree.

\section{References}

1. Daoust R, Cantero A. The numeric proportions of cell types in rat liver during carcinogenesis by 4-dimethylaminoazobenzene (DAB). Cancer Res 1959;19:757-762. 
2. Alpini G, Lenzi R, Sarkozi L, Tavoloni N. Biliary physiology in rats with bile ductular cell hyperplasia. Evidence for a secretory function of proliferated bile ductules. J Clin Invest 1988;81:569_ 578.

3. Alpini G, Phillips JO, LaRusso NF. The biology of the biliary epithelia. In: Arias I, Boyer J, Fausto N, Jakoby W, Schachter D, Shafritz DA, eds. The liver: biology and pathobiology. 3rd ed. New York: Raven, 1994:623-653.

4. Roberts SK, LaRusso NF. Pathobiology of biliary epithelia. Curr Opin Gastroenterol 1994;10:526-533.

5. Alvaro D, Cho WKC, Mennone A, Boyer JL. Effect of secretin on intracellular $\mathrm{pH}$ regulation in isolated rat bile duct epithelial cells. J Clin Invest 1993;92:1314-1325.

6. Lenzen R, Alpini G, Tavoloni N. Secretin stimulates bile ductular secretory activity through the cAMP system. Am J Physiol 1992; 263:G527-G532.

7. Kato A, Gores GJ, LaRusso NF. Secretin stimulates exocytosis in isolated bile duct epithelial cells by a cyclic AMP-mediated mechanism. J Biol Chem 1992;267:15523-15529.

8. Tietz P, Alpini G, Pham LD, LaRusso NF. Somatostatin inhibits secretin-induced ductal choleresis in vivo and exocytosis by cholangiocytes. Am J Physiol 1995;269:G110-G118.

9. Fitz JG, Basavappa S, McGill J, Melhus O, Cohn JA. Regulation of membrane chloride currents in rat bile duct epithelial cells. J Clin Invest 1993;91:319-328.

10. Basavappa S, Middleton J, Mangel AW, McGill JM, Cohn JA, Fitz JG. $\mathrm{Cl}^{-}$and $\mathrm{K}^{+}$transport in human biliary cell lines. Gastroenterology 1993;104:1796-1805.

11. Strazzabosco M, Mennone A, Boyer JL. Intracellular pH regulation in isolated rat bile duct epithelial cells. J Clin Invest 1991;87: 1503-1512.

12. Yang L, Faris RA, Hixson DC. Long-term culture and characteristics of normal rat liver bile duct epithelial cells. Gastroenterology 1993;104:840-852.

13. Alpini G, Roberts S, Phinizy J, Robertson W, Gubba S, Colegio O, LeSage G, LaRusso NF. Heterogeneity of the proliferative capacity of rat cholangiocytes (abstr). Gastroenterology 1995; 1098:A1025.

14. Slott PA, Liu MH, Tavoloni N. Origin, pattern, and mechanism of bile duct proliferation following biliary obstruction in the rat. Gastroenterology 1990; 99:466-477.

15. Alpini G, Lenzi R, Zhai W-R, Liu MH, Slott PA, Paronetto F, Tavoloni $\mathrm{N}$. Isolation of a nonparenchymal liver cell fraction enriched in cells with biliary epithelial phenotypes. Gastroenterology 1989; 97:1248-1260.

16. Alpini G, Lenzi R, Zhai W-R, Slott PA, Liu MH, Sarkozi L, Tavoloni $N$. Bile secretory function of intrahepatic biliary epithelium in the rat. Am J Physiol 1989;257:G124-G133.

17. LaRusso NF, Wiesner RH, Ludwig J, MacCarty RL. Primary sclerosing cholangitis. N Engl J Med 1984;310:899-903.

18. Alpini G, Aragona E, Dabeva M, Salvi R, Shafritz DA, Tavoloni N. Distribution of albumin and alpha-fetoprotein mRNAs in normal, hyperplastic, and preneoplastic rat liver. Am J Pathol 1993;141: 623-632.

19. Desmet V, Roskams T, Van Eyken P. Ductular reaction in the liver. Pathol Res Pract 1995:191:513-524.

20. Sirica AE. Ductular hepatocytes. Histol Histopathol 1995:10: 433-456.

21. Sirica AE, Gainay TW, Mumaw VR. Ductular hepatocytes. Evidence for a bile ductular cell origin in furan-treated rats. Am J Pathol 1994;145:375-383.

22. Sirica AE. Biology of biliary epithelial cells. Prog Liver Dis 1992; 10:63-87.

23. Sirica AE, Mathis GA, Sano N, Elmore LW. Isolation, culture, and transplantation of intrahepatic biliary epithelial cells and oval cells. Pathobiology 1990;58:44-64.

24. Alpini G, Ulrich II C, Phillips J, Pham L, Miller L, LaRusso NF.
Upregulation of secretin receptor gene expression in rat cholangiocytes after bile duct ligation. Am J Physiol 1994;266:G922G928.

25. Fausto N, Webber EM. Liver regeneration. In: Arias IM, Boyer JL, Fausto N, Jakoby WB, Schachter D, Shafritz DA, eds. The liver: biology and pathobiology. 3rd ed. New York: Raven, 1994:10591084.

26. Fausto N, Mead JE. Regulation of liver growth: protooncogenes and transforming growth factors. Lab Invest 1989;60:4-13.

27. Michalopoulos GK. Liver regeneration: molecular mechanisms of growth control. FASEB J 1990;4:176-187.

28. Polimeno L, Azzarone A, Zeng QH, Panella C, Subbotin V, Carr B, Bouzahzah B, Francavilla A, Starzl TE. Cell proliferation and oncogene expression after bile duct ligation in the rat: evidence of a specific growth effect on bile duct cells. Hepatology 1995; 21:1070-1078.

29. Grisham JW, Porta EA. Origin and fate of proliferated ductal cells in the rat: electron microscopic and autoradiographic studies. Exp Mol Pathol 1964;3:242-261.

30. Yang L, Faris RA, Hixson DC. Phenotypic heterogeneity within clonogenic ductal cell populations isolated from normal adult rat liver. Proc Soc Exp Biol Med 1993;204:280-288.

31. Grisham JW. A morphological study of deoxyribonucleic acid synthesis and cell proliferation, in regenerating rat liver: autoradiography with thymidine-H3. Cancer Res 1962;22:842-849.

32. Haber BA, Mohn KL, Diamond RH, Taub R. Induction patterns of 70 genes during nine days after partial hepatectomy define the temporal course of liver regeneration. J Clin Invest 1993;91: 1319-1326.

33. Higgins GM, Anderson RM. Experimental pathology of the liver. I. Restoration of the liver of the white rat following partial surgical removal. Arch Pathol 1931;12:186-202.

34. Weibel ER, Gomez D. A principle for counting tissue structure on random sections. Appl Physiol 1962;17:3443-3448.

35. Weibel ER, Staubli W, Gnagi HR, Hess PA. Correlated morphometric and biochemical studies on the liver cells. Morphometric model, stereological methods, and normal morphometric data for rat liver. J Cell Biol 1969;42:69-91.

36. Ishii M, Vroman B, LaRusso NF. Isolation and morphological characterization of bile duct epithelial cells from normal rat liver. Gastroenterology 1989;97:1236-1247.

37. Alpini G, Phillips JO, Vroman B, LaRusso NF. Recent advances in the isolation of liver cells. Hepatology 1994;20:494-514.

38. Rutemberg AM, Kim H, Fishbein JW, Hanker JS, Wasserkrug HL, Seligman AM. Histochemical and ultrastructural demonstration of g-glutamyltranspeptidase activity. J Histochem Cytochem 1969:17:517-526.

39. Alpini G, Roberts SK, Kuntz SM, Ueno Y, Gubba S, Podila P, LeSage G, LaRusso NF. Morphologic, molecular and functional heterogeneity of cholangiocytes from normal rat liver. Gastroenterology 1996;110:1637-1643.

40. Edwards AM, Lucas CM. Phenobarbital and some other liver tumor promoters stimulate DNA synthesis in cultured rat hepatocytes. Biochem Biophys Res Commun 1985;131:103-108.

41. Strauss KI, Jacobowitz DM. Quantitative measurement of calretinin and $\beta$-actin mRNA in rat brain micropunches without prior isolation of RNA. Mol Brain Res 1993;20:229-239.

42. Haines DS, Gillespie DH. RNA abundance measured by a lysate RNase protection assay. Bio Techniques 1992;12:5736-5741.

43. Danielson P, Forss-Petter S, Brow M, Calavetta L, Douglass J, Milner J, Sutcliffe G. p1B15: a cDNA clone of the rat mRNA encoding cyclophilin. DNA 1988; 7:261-267.

44. Roberts S, Kuntz S, Gores G, LaRusso NF. Regulation of bicarbonate-dependent ductular secretion assessed by lumenal micropuncture of isolated rodent intrahepatic bile ducts. Proc Natl Acad Sci USA 1993; 90:9080-9084.

45. Wenzl E, Machen T. Intracellular pH dependence of buffer capac- 
ity and anion exchange in the parietal cell. Am J Physiol 1989; 257:G741-G747.

46. Lindsey AE, Schneider K, Simmons DM, Baron R, Lee BS, Kopito RR. Functional expression and subcellular localization of an anion exchanger cloned from choroid plexus. Proc Natl Acad Sci USA 1990; 87:5278-5282.

47. Sand TE, Thoresen GH, Refsnes M, Christoffersen T. Growthregulatory effects of glucagon, insulin, and epidermal growth factor in cultured hepatocytes. Temporal aspects and evidence for bidirectional control by cAMP. Dig Dis Sci 1992;37:84-92.

48. Tsuji H, Okamoto Y, Kikuchi E, Matsumoto M, Nakano H. Prostaglandin E2 and rat liver regeneration. Gastroenterology 1993; 105:495-499.

49. Cameron GR, Prasad LBM. Recovery from biliary obstruction after spontaneous restoration of the obstructed common bile-duct. J Pathol Bacteriol 1960;80:127-136.

50. Bhathal PS, Gall JAM. Deletion of hyperplastic biliary epithelial cells by apoptosis following removal of the proliferative stimulus. Liver 1985; 5:311-325.
51. Jacobs JM, Pretlow TP, Fausto N, Pitis AM, Pretlow TG. Separation of two populations of cells with gamma-glutamyl transpeptidase from carcinogen-treated rat liver. J Natl Cancer Inst 1981; 66:967-973.

52. Yaswen P, Hayner NT, Fausto N. Isolation of oval cells by centrifugal elutriation and comparison with other cell types from normal and preneoplastic rat liver. Cancer Res 1984;44:324-331.

Received March 28, 1996. Accepted August 16, 1996.

Address requests for reprints to: Gianfranco Alpini, Ph.D., Department of Internal Medicine, Texas A\&M University Health Science Center, College of Medicine, Building 147, Olin E. Teague Veterans' Center, 1901 South 1st Street, Temple, Texas 76504. Fax: (817) 771-5725.

Supported by a grant award from the Scott \& White Hospital and Texas A\&M University Health Science Center, College of Medicine (to G.A. and G.L.). 